\title{
Експериментальне дослідження морфологічних змін у підшлунковій залозі після іiі резекціі із застосуванням електрохірургічних інструментів
}

\author{
О. Ю. Усенко ${ }^{1,2}$, К. Г. Валіхновська ${ }^{1}$, І. М. Савицька ${ }^{2}$, В. В. Ліходієвський ${ }^{3}$
}

${ }^{1}$ Національна медична академія післядипломної освіти імені П. Л. Шупика, м. Київ, ${ }^{2}$ Національний інститут хірургії та трансплантології імені О. О. Шалімова НАМН України, м. Київ, ${ }^{3}$ Національний медичний університет імені О. О. Богомольця, м. Київ

\section{Experimental investigation of morphological changes in pancreatic gland after its resection, using electrosurgical instruments}

\author{
O. Yu. Usenko ${ }^{1,2}$, K. G. Valikhnovska ${ }^{1}$, I. M. Savytska ${ }^{2}$, V. V. Likhodiyevskyi ${ }^{3}$ \\ ${ }^{1}$ Shupyk National Medical Academy of Postgraduate Education, Kyiv, \\ ${ }^{2}$ Shalimov National Institute of Surgery and Transplantology, Kyiv, \\ ${ }^{3}$ Bogomolets National Medical University, Kyiv
}

Реферат

Мета. Визначити особливості морфологічних змін у підшлунковій залозі (П3) після резекційних втручань із застосуванням високоенергетичних електрохірургічних інструментів (BEEXI) та стандартної хірургічної техніки.

Матеріали і методи. В умовах експерименту виконували резекцію ПЗ білим лабораторним щурам, використовуючи стандартну хірургічну техніку та BEEXI в режимі зварювання (DA2), біполярному та монополярному режимах. Гістологічно ПЗ досліджували безпосередньо після виконання операції та через 3, 7 і 21 добу, застосовуючи світлооптичний мікроскоп Leica DM500. Результати. Після застосування стандартної хірургічної техніки в ранні строки виникало більш виражене запалення та швидше збільшувався об'єм новоутвореної сполучної тканини, ніж після використання електрохірургічних методів. Після всіх видів електрорезекції в новоутвореній тканині формувались протоки, чого не спостерігали після використання стандартної техніки. Після біполярного зварювання резектована поверхня мала менше крововиливів, ніж після використання хірургічних ножиць. Після резекції, виконаної з використанням монополярного зварювання, утворювався менш щільний коагуляційний прошарок, ніж після резекції, виконаної з використанням біполярного зварювання, а через 21-у добу в зоні резекції формувався значно більший об’єм сполучної тканини та зберігалися більш виражені ознаки запалення, ніж після використання біполярного методу.

Висновки. У разі використання всіх видів електрорезекції скорочується тривалість виконання оперативного втручання, зменшується ризик виникнення кровотечі, на резектованій поверхні утворюється герметичне з'єднання, не ускладнючи процесів відновлення

Ключові слова: резекція підшлункової залози; електрозварювання; коагуляційний некроз; електрохірургія; біполярне зварювання; монополярне зварювання.

\section{Abstract}

Objective. To determine a peculiarities of morphological changes in pancreatic gland after resectional operations, using the highenergy electric surgical instruments (HEESI) and standard surgical procedure.

Materials and methods. In conditions of experiment a pancreatic resection was performed in white laboratory rats, using a standard surgical procedure and a high-energy electro-surgical instruments (HEESI) in a welding regime (DA2), bipolar and monopolar regimes. Histological investigation of pancreatic gland was done immediately postoperatively and in 3, 7 and 21 days, using a lightoptical microscope Leica DM500.

Results. In early terms after application of a standard surgical procedure a more severe inflammation have had occur and more rapidly the newly created connective tissue volume enhanced, than after application of electro-surgical methods. After all kinds of electroresection performed in a newly created tissue the ducts have been formatted, what was not observed after application of a standard procedure. After bipolar welding the surface resected have had lesser hematomas, than after application of surgical scissors. After resection, performed, using monopolar welding, a less dense coagulation layer have been created, than after resection, performed with application of a bipolar welding, in 21 days in the resection zone a significantly more volume of connective tissue was created and more significant signs of inflammation persisted, than after application of a bipolar method

Conclusion. While applying of all kinds of electro-resection the operative intervention duration shortens, the hemorrhage occurrence risk reduces, hermetic joints on the surface resected are created, and the restoration processes do not complicate.

Keywords: pancreatic resection; electric welding; coagulation necrosis; electrosurgery; bipolar welding; monopolar welding. 
У сучасній хірургічній практиці широко використовують BEEXI під час оперативних втручань на органах дихальної, травної систем, в урології та гінекології [1 - 3]. Під впливом високочастотного струму в тканинах органів відбуваються хімічні та фізичні процеси. Розріз, коагуляція (біполярна, монополярна), електрозварювання - це основні прийоми сучасної хірургії [4 - 6]. У разі застосування високочастотної електрозварювальної технології істотно зменшується тривалість оперативного втручання, не передбачається використання шовних матеріалів та інших засобів, зводиться до мінімуму тривалість кровотечі, значно знижується біль у післяопераційній рані [7, 8]. Проте відомостей про зміни, які виникають в тканинах ПЗ після застосування електрохірургічних інструментів під час резекційних втручань мало. Хірурги мають бути обізнаними щодо можливостей та особливостей використання електрохірургічних інструментів під час виконання оперативних втручань.

Мета дослідження: порівняти зміни в тканинах ПЗ після експериментальних хірургічних втручань, виконаних із застосуванням стандартної хірургічної техніки та електрохірургічних інструментів.

\section{Матеріали і методи дослідження}

Проведено сліпе контрольоване експериментальне дослідження з метою встановлення морфологічних особливостей перебудови ПЗ після експериментальних хірургічних втручань, виконаних 40 шестимісячним білим щурам масою тіла 190 - 210 г, яких утримували в умовах експериментальної клініки-віварію за природного світлового режиму, звичайної температури, вологості та з вільним доступом до їжі та води. У відповідності до поставлених завдань тварин розподілили на групи: 1-ша - 10 тварин, яким виконали резекцію частини ПЗ із застосуванням стандартної хірургічної техніки; 2-га - 30 тварин, яким виконали резекцію частини ПЗ із використанням ВEEXI. Оскільки BEEXI використовують в різних режимах, тварин 2-ї групи розподілили на підгрупи: $2 \mathrm{a}-10$ тварин, яким виконали резекцію частини ПЗ із використанням BEEXI в монополярному режимі; 26 -10 тварин, яким виконали резекцію частини ПЗ із використанням BEEXI в біполярно-

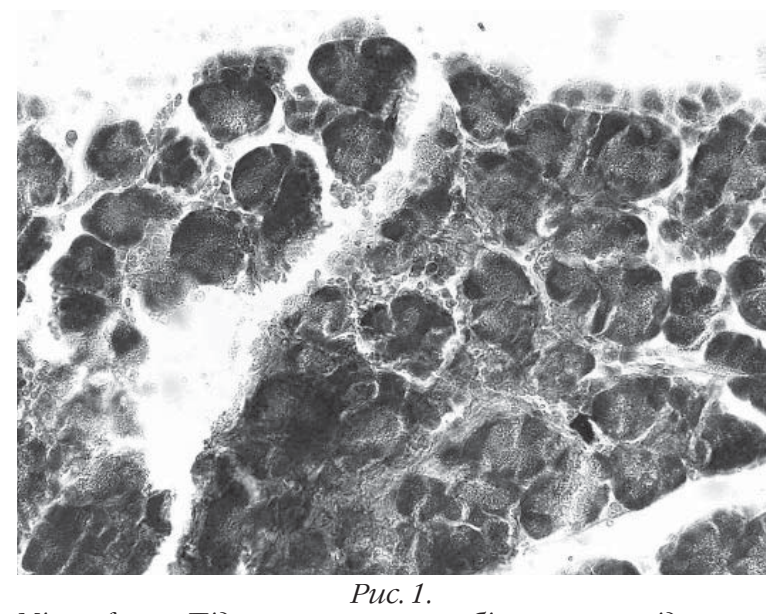

Мікрофото. Підилункова залоза білого иура під зоноюо резекції, виконаної хірургічними ножииями. Гострий дослід Забарвлення азур-2-еозином. 3б. $\times 100$. му режимі; 10 - тварини, яким виконали резекцію частини ПЗ із використанням BEEXI в режимі DA2.

Дослідження з лабораторними тваринами проводили з дотриманням вимог Закону України №3447-IV від 21.02.2006 р. «Про захист тварин від жорсткого поводження» та «Науково-практичних рекомендацій по утриманню лабораторних тварин і роботі з ними» ДФЦ МОЗ України (Протокол № 8 від 22.06.2012р.). Оперативні втручання виконували під загальним внутрішньочеревним наркозом (0,2 мл 5\% розчину тіопенталу натрію та 0,4 мл 1\% розчину пропофолу) в асептичних умовах.

Для профілактики ускладнень вводили одноразово розчин біциліну-5 у дозі 1 млн ОД на 1 кг живої маси тіла.

Після закінчення оперативного втручання тварин утримували в приміщенні з підвищеною температурою повітря $\left(30^{\circ} \mathrm{C}\right)$ до відновлення поведінкової активності та захисних рефлексів, у подальшому - у звичних умовах.

3 метою післяопераційного знеболювання вводили розчин декскетопрофену 3 - 5 мг/кг підшкірно протягом перших 3 діб після операції.

Тварин виводили з експерименту внутрішньочеревним передозуванням 10\% розчину тіопенталу натрію через 3, 7 та 21 добу після оперативного втручання.

Для проведення гістологічного дослідження видаляли ділянку ПЗ в зоні резекції разом з навколишньою паренхімою безпосередньо після операції та через 3, 7 та 21 добу, після чого матеріал фіксували в розчині формальдегіду з об'ємною часткою 10\% 24 год, ущільнювали в парафіні за загальноприйнятою схемою. Зрізи товщиною 7 мкм забарвлювали гематоксиліном та еозином, пікрофуксином за ван Гізоном. Для вивчення гістологічних препаратів застосували світлооптичний мікроскоп Leica DM500, фотодокументування здійснювали за допомогою камери Leica ICC50 HD.

\section{Результати}

Безпосередньо після резекції, виконаної хірургічними ножицями, кровоносні судини ПЗ розширювалися, артерії під зоною резекції втрачали тонус. На резектованій поверхні утворювався нещільний згорток, який не міг бути надійним пломбовочним захистом від кровотечі, тому в більшості спостережень резекція супроводжувалася вираженим повнокров'ям та крововиливами в строму (рис. 1). Крім того, місцями множинні крововиливи під зоною резекції зливалися у великі поля, порушуючи трофіку паренхіми, що зазнавала дистрофічних змін.

Через 3 доби в зоні резекції навколо вогнища некрозу формувалась грануляційна тканина. На порушення судинної проникності вказували плазморагія і діапедезні крововиливи, набряк строми навіть на віддаленні. Запалення з рясною лімфоцитарною інфільтрацією охоплювало тканину ПЗ.

На 7-му добу в зоні резекції утворювався значний об'єм грануляційної тканини, в якій спостерігали вогнища некрозу, строма набрякла як під зоною резекції, так і на віддаленні. Прояви запалення навколо зони резекції були виражені, на віддаленні - дещо згаслі.

На 21-шу добу утворювались зрощення з петлями тонкої кишки. В тканинах навколо зони резекції зберігались явища запалення. Новоутворена тканина оточувала некро- 


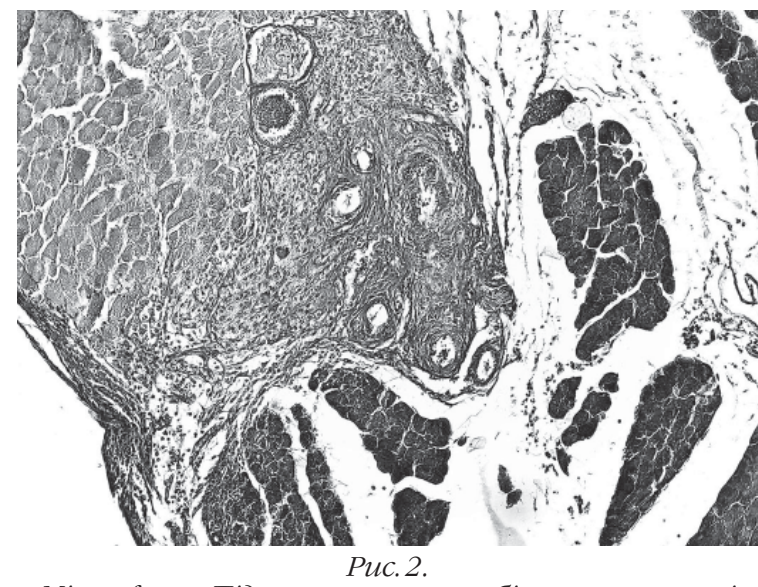

Мікрофото. Підилункова залоза білого шура в зоні резекиї. Зварювання в режимі DA2. Термін спостереження - 7-ма доба

забарвлення пікробуксином за ван Гізоном. Зб. $\times 100$.

тизовані ділянки паренхіми. Дещо відновлювався функціональний стан паренхіматозних клітин. Прояви судинної реакції ставали менш вираженими.

Таким чином, після резекції, виконаної стандартними хірургічними ножицями, виникали альтеративні зміни, що супроводжувалися циркуляторними розладами навколо вогнищ деструкції панкреатоцитів, процес набував каскадного характеру з формуванням вогнищ колікваційного некрозу, навколо яких на 7-му добу формувалися сполучнотканинні капсули.

Часткове відновлення функціонального стану паренхіматозних клітин з помірним згасанням у стромі проявів запалення та мікросудинної реакції спостерігали на 21-шу добу.

Безпосередньо після резекції, виконаної з використанням BEEXI в режимі DA2, на поверхні зони резекції коагуляційний прошарок, сформований термічно коагульованою згорнутою плазмою, мав щілини. Під ним паренхіма була значно ущільнена через зменшення об'єму клітинних тіл, втрату рідини та внутрішньоклітинну коагуляцію. Кровоносні судини закриті, здавлені. Спостерігали невеликі поодинокі вогнища геморагії, мозаїчність розподілу ділянок ущільненої тканини і ділянок з дезагрегацією паренхіматозних клітин.

Через 3 доби в зоні резекції коагуляційний струп частково фрагментувався, разом з некротизованою паренхімою ПЗ його оточував тонкий прошарок фібробластів. Ознаки запалення в навколишніх тканинах виражені. Морфофункціональні зміни строми під зоною резекції спостерігали перш за все у всіх ланках мікроциркуляторного русла: стаз, відшарування ендотеліоцитів у просвіт судин, плазморагічне просочування судинних стінок та паравазальної сполучної тканини.

Через 7 діб фрагменти коагуляційного прошарку та некротизовану внаслідок зварювання тканину ПЗ оточувала сполучнотканинна капсула, в якій спостерігали новоутворені протоки і кровоносні судини. Зберігалися ознаки запалення (рис. 2).

На 21-шу добу формувалася досить зріла та пухка сполучна тканина, що містила значну кількість новоутворених проток та судин. У ній були також розташовані фраг-

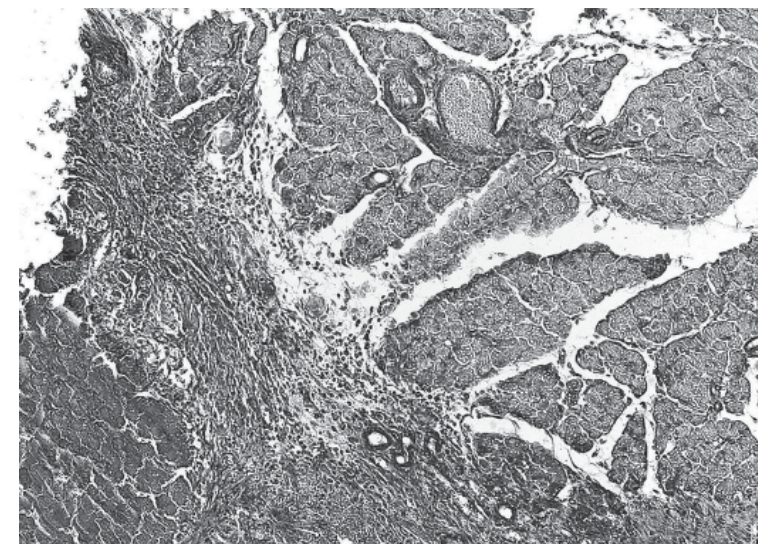

Puc.3.

Мікрофото. Підилункова залоза білого иура в зоні впливу. Біполярне зварювання. Термін спостереження - 7-ма доба

Зона коагуляціинного некрозу оточена сполучнотканинною капсулою.

Забарвлення гематоксиліном та еозином. 3б. ×100.

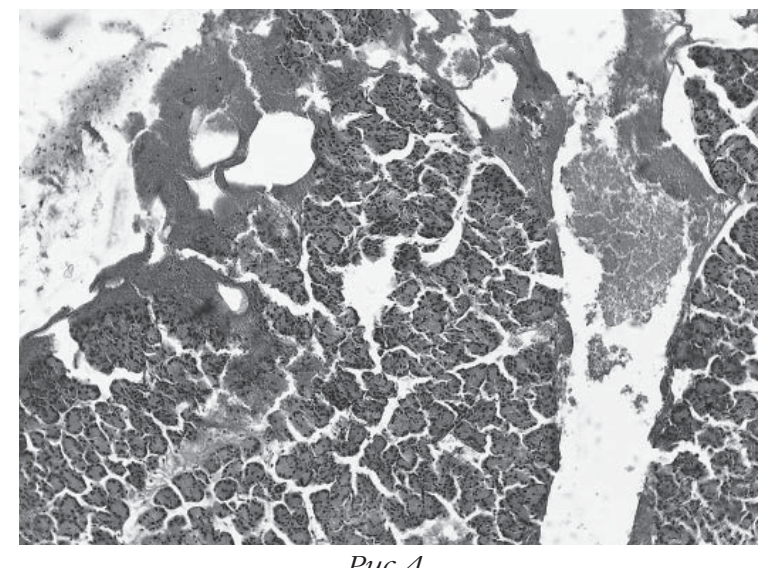

Puc. 4.

Мікрофото. Підилункова залоза білого шура в зоні впливу. Монополярне зварювання, вихідна потужність $100 \mathrm{Bm}$. Гострий дослід.

Забарвлення гематоксиліном та еозином. 3б. ×100.

менти коагуляційного струпу. Новоутворена тканина та навколишня паренхіма мали помірні ознаки запалення.

Таким чином, у зоні резекції після застосування BEEXI в режимі DA2 спостерігали ущільнення тканини і випаровування рідини. На 3-тю добу пластичні функції мали менші прояви, проте на 7-му добу формувався значний об’єм грануляційної тканини. Через 21 добу значно знижувалися ознаки запалення і набряк строми, ділянка некрозу, що утворилася в результаті термічного впливу, зменшувалася в розмірах за рахунок заміщення сполучною тканиною та резорбції переважно макрофагами, наявність новоутворених проток свідчила про відновлення функціональної активності органа.

Після біполярного зварювання на резектованій поверхні формувався коагуляційний прошарок, під яким у тканині ПЗ утворювалися лакуни, крововиливів було менше, ніж після використання хірургічних ножиць, судини тромбувала згорнута кров. Термічно пошкоджену паренхіму разом з фрагментами струпу вже на 3-тю добу починала оточувати сполучнотканинна капсула, яка на 7му та 21-шу добу потовщувалася, від неї на 21-шу добу вглиб некротизованої ділянки проростали тяжі сполуч- 
ної тканини і пошкоджена тканина починала заміщуватись сполучною. Ознаки запалення, помірно виражені на 7-му добу, дещо згасали на 21-шу добу.

Таким чином, через 7 діб після резекції ПЗ з використанням BEEXI в режимі біполярного зварювання в стромі спостерігали явища плазморагії (рuс. 3), яка в ранні строки після операції виконує позитивну функцію, оскільки в строму ПЗ потрапляють плазмові інгібітори протеаз, які інактивують протеази, що звільняються з клітин внаслідок іх руйнування, і в такий спосіб запобігають подальшому пошкодженню збереженої частини органа. На резектованій поверхні починаючи з 3-ї доби формувався сполучнотканинний рубець, товщина якого збільшувалась до 21-ї доби.

Безпосередньо після резекції, виконаної за допомогою BEEXI в режимі монополярного зварювання, утворювався карбонізований коагуляційний прошарок, менш щільний, ніж після застосування біполярного зварювання. В тканині, розташованій нижче, як і після біполярного зварювання, спостерігали поодинокі крововиливи та тромбовані кровоносні судини, пошкоджена була переважно інтерстиційна тканина (рис.4).

Через 3 доби паренхіма ПЗ мала вигляд мозаїчної картини внаслідок чергування слабо відокремлених тонким прошарком фібробластів вогнищ коагуляційного некрозу з ділянками дезкомплексації ацинусів та зонами збереженої гістоструктури.

На 7-му добу некротизовану внаслідок пошкодження паренхіму ПЗ оточувала сполучнотканинна капсула, коагуляційний прошарок фрагментувався.

Через 21 добу гострота запальної реакції знижувалась, на віддалених від зони резекції ділянках панкреатоцити ставали більш функціонально активними, про що свідчило часткове відновлення зональності їх цитоплазми.

Таким чином, на 7-му добу після резекції ПЗ із застосуванням монополярного зварювання поряд із запаленням, що тривало, з'являлися ознаки функціонального відновлення паренхіми, на резектованій поверхні в грануляційній тканині новоутворені протоки брали участь у компенсаторних процесах. Через 21 добу в зоні резекції формувався значно більший об'єм сполучної тканини, ніж після використання біполярного зварювання, а також зберігалися більш виражені ознаки запалення.

\section{Обговорення}

Виконуючи резекційні втручання на ПЗ із застосуванням BEEXI, необхідно враховувати їх можливості та особливості.

Після використання всіх досліджених електрохірургічних методів спостерігали надійний гемостаз, який забезпечувало утворення коагуляційного струпа на резектованій поверхні, в новоутвореній тканині формувались протоки, що значно зменшувало ризик виникнення кровотечі та впливало на відновні процеси в післяопераційному періоді. Проте після застосування BEEXI в режимі DA2 площа термічно пошкодженої тканини була менша, ніж після біполярного та монополярного зварювання. Після використання стандартних хірургічних ножиць в ранні терміни виникали більш виражене запалення, кровотеча з резектованої поверхні, крововиливи в строму, збільшувався об’єм новоутвореної сполучної тканини, що в подальшому могло спричинити виникнення післяопераційної кровотечі, збільшити тривалість відновних процесів, вплинути на формування значного об'єму рубцевої тканини.

\section{Висновки}

1. Після використання всіх досліджених електрохірургічних методів забезпечувався надійний гемостаз за рахунок утворення коагуляційного струпу на резектованій поверхні та згортання крові в судинах під зоною резекціiі. Нижче розташовані судини були різко розширені, зберігали прохідність. У разі використання стандартної техніки виникали кровотеча з резектованої поверхні та крововиливи в строму.

2. У зоні резекції після електрозварювання спостерігали більш значне ущільнення тканини і випаровування рідини, ніж після біполярного та монополярного зварювання, проте площа термічно пошкодженої тканини була менша.

3. У разі використання стандартної хірургічної техніки в ранні терміни виникало більш виражене запалення з домінуванням нейтрофільної інфільтрації, ніж після електрохірургічних методів, швидше збільшувався об'єм новоутвореної сполучної тканини, що в пізні терміни могло призвести до формування значного об'єму рубцевої тканини.

4. Після всіх видів електрорезекції в новоутвореній тканині формувались протоки, чого не спостерігали після використання стандартної техніки.

5. Після монополярного зварювання утворювався менш щільний коагуляційний прошарок, ніж після біполярного, через 21 добу в зоні резекції формувався більший об'єм сполучної тканини та зберігались виражені ознаки запалення.

6. У разі використання всіх видів електрорезекції скорочувалась тривалість оперативного втручання, зменшувався ризик виникнення кровотечі, на резектованій поверхні утворювалось герметичне з'єднання, відновні процеси в досліджені терміни не ускладнювались.

\section{References}

1. Morris ML, Tucker RD, Baron TH, Song LM. Electrosurgery in gastrointestinal endoscopy: principles to practice. Am J Gastroenterol. 2009 Jun;104(6):1563-74. doi: 10.1038/ajg.2009.105.

2. Linchevskyy O, Makarov A, Getman V. Lung sealing using the tissuewelding technology in spontaneous pneumothorax. Eur J Cardiothorac Surg. 2010 May;37(5):1126-8. doi: 10.1016/j.ejcts.2009.11.017.

3. Shapovalova YA. Criterions of efficacy of the soft tissues electric welding for the hemostasis guaranteeing in laparoscopic operations. Klinichna khirurgiia. isep: 2015;(8):17-20. [In Ukrainian]

4. You H, Yang Q. The advance of electrosurgery equipment. Zhongguo Yi Liao Qi Xie Za Zhi. 2012 Jul;36(4):285-7. [In Chinese]

5. Alkatout I, Schollmeyer T, Hawaldar NA, Sharma N, Mettler L. Principles and safety measures of electrosurgery in laparoscopy. JSLS. 2012 Jan-Mar;16(1):130-9. doi: 10.4293/108680812X13291597716348.

6. Huschak G, Steen M, Kaisers UX. Principles and risks of electrosurgery. Anasthesiol Intensivmed Notfallmed Schmerzther. 2009 Jan; 44(1):10 3. doi: 10.1055/s-0028-1128179. [In German]

7. Korsak AV, Likhodiievskyyi VV, Kryvosheyeva OI, Chernets OV, Chaikovskyi YuB. Ultrastruktura nevromy travmovanoho peryferiyinoho nerva pislia operatyvnoho likuvannia z vykorystanniam vysokachastotnoi elektrozvariuvalnoi tekhnolohii ta farmakolohichnoi korektsii, Svit medytsyny ta biolohii. 2015; (3/52):112-8. [In Ukrainian]

8. Aird LN, Brown CJ. Systematic review and meta-analysis of electrocautery versus scalpel for surgical skin incisions. Am J Surg. 2012 Aug;204(2):216-21. doi: 10.1016/j.amjsurg.2011.09.032. 